Stawomir Chrost*

Kielce

\title{
Człowiek podobny do Boga przez przebaczenie w nauczaniu św. Jana Chryzostoma
}

Przeżywamy Rok Miłosierdzia. We współczesnym świecie kryzys miłosierdzia idzie w parze z kryzysem przebaczenia. Papież Franciszek w bulli Misericordiae Vultus, wydanej z okazji roku jubileuszowego, zauważa, że:

W niektórych przypadkach wydaje się nawet, że zanika już samo słowo przebaczenie. Jednak bez doświadczenia przebaczenia pozostaje nam droga bezpłodna i sterylna, jakbyśmy żyli w jakimś miejscu pustynnym i odosobnionym. Nadszedł znowu czas dla Kościoła, aby przyjąć na siebie radosne głoszenie przebaczenia. To jest czas powrotu do tego, co istotne, aby wziąć na siebie słabości i trudności naszych braci. Przebaczenie to siła, która przywraca do nowego życia i dodaje odwagi, aby patrzeć w przyszłość z nadzieją (MV, nr 10)ํ.

Wydaje się, że warto w realiach dzisiejszego świata przypominać pedagogię Ojców Kościoła dotyczącą między innymi przebaczenia. Celem niniejszego tekstu jest refleksja nad fenomenem przebaczenia w nauczaniu jednego z pierwszych pedagogów chrześcijańskich, jakim był św. Jan

* Ks. dr hab. Sławomir Chrost, prof. UJK, jest kierownikiem Zakładu Pracy Socjalnej i Integracji Społecznej w Instytucie Pedagogiki i Psychologii Uniwersytetu Jana Kochanowskiego w Kielcach. Adres: Instytut Pedagogiki i Psychologii UJK, ul. Krakowska 11, 25-029 Kielce; e-mail: schrost@op.pl.

${ }^{1}$ Franciszek, Bulla Misericordiae Vultus ogłaszająca Nadzwyczajny Jubileusz Miłosierdzia (Poznań: Pallottinum, 2015). 
Chryzostom. Jego nauczanie zawarte jest głównie w komentarzach do Pisma Świętego. Złotousty wyjaśnia, czym jest przebaczenie, komentując przede wszystkim teksty Ewangelii według św. Mateusza (rozdział VI) oraz List św. Pawła do Galatów (rozdział VI). Aby zrozumieć istotę przebaczenia, należy jednak najpierw ukazać myśl antropologiczną Antiocheńczyka, sięgając do jego homilii na Księgę Rodzaju oraz pisma Do Teodora po jego upadku.

Artykuł przypomina najważniejsze fakty z życia Jana Chryzostoma, ukazuje go jako pedagoga, aby następnie przybliżyć naukę o człowieku potrzebującym przebaczenia i przebaczającym. „Nic nas tak Bogu podobnymi nie czyni, jak gdy złym i takim, którzy nam krzywdę czynią, przebaczymy, jak to Chrystus uczył mówiąc, że słońce Jego wschodzi nad złymi i dobrymi”2.

\section{Jan Chryzostom - życie}

Jan Chryzostom ${ }^{3}$ urodził się około 347 roku (według źródeł zachodnich około 349 roku) w Antiochii Syryjskiej, w zamożnej rodzinie. Jego ojciec był wysokiej rangi oficerem. Zmarł wkrótce po narodzinach Jana, który był wychowywany przez matkę Antuzę, pochodzącą z Grecji. Jan był uczniem pogańskiego filozofa Libaniosa i Ammiana Marcellina, najwybitniejszego historyka późnego antyku. W swoich mowach naśladował styl Demostenesa. Chrzest przyjął, mając 20 lat, po czym został lektorem u boku biskupa Antiochii Melecjusza. Prowadził ascetyczne życie. W 371 roku opuścił Antiochię i udał się na pustynię. Po sześciu latach bycia pustelnikiem powrócił i przyjął święcenia kapłańskie. Od 381 roku nauczał w kościołach Antiochii, a dzięki swym zdolnościom krasomówczym zyskał przydomek „Złotousty” i stał się sławnym kaznodzieją. W 397 roku został patriarchą Konstantynopola.

W stolicy Chryzostom odprawiał nabożeństwa, w których chwalił zasady ubóstwa, wstrzemięźliwości i jałmużny, a jednocześnie piętnował nadużycia na dworze cesarskim. Jak pisze Hans von Campenhausen: „Chryzostom nie przyczynił się do dogmatycznej rozbudowy teorii chrystologicznej i zbytnio się nie interesował aktualnymi sporami w tej dziedzinie. Zależy mu zawsze

* Por. John N. D. Kelly, Złote Usta. Jan Chryzostom - asceta, kaznodzieja, biskup, thum. Katarzyna Krakowczyk (Bydgoszcz: Homini, 2001). milia 19

2 Jan Chryzostom, Homilie na Ewangelię św. Mateusza (Kraków: WAM, 2003), Ho-

3 Por. John N. D. Kelly, Złote Usta. Jan Chryzostom - asceta, kaznodzieja, biskup, thum. Katarzyna Krakowczyk (Bydgoszcz: Homini, 2001). 
na pobudzeniu serca, energii moralnej, czystej miłości i nieobłudnym, duchowym usposobieniu" ". Jan Chryzostom zwracał uwagę przede wszystkim na praktyczny wymiar miłości w życiu chrześcijanina. Sam dawał świadectwo ubogiego i pełnego czynów miłosierdzia życia. Campenhausen notuje między innymi: „Posiłki spożywał zasadniczo sam, wymagał oszczędności i surowości obyczajów i chętnie podkreślał, że opieka nad ubogimi, działalność w dziedzinie czysto duchowej i ascetycznej wydaje się mu jedynym istotnym i ważnym zadaniem piastowanego urzędu"s.

W 403 roku cesarzowa Eudoksja, żona cesarza Arkadiusza, wraz z biskupami na synodzie „pod dębem” doprowadziła do pozbawienia Jana urzędu i zesłania na banicję. Początkowo wyroku synodu nie wykonano. Ponieważ jednak Jan kontynuował wystapienia przeciwko cesarzowej, ostatecznie wygnano go do Armenii. Stamtąd słał krytyczne listy do Konstantynopola, dlatego postanowiono zesłać go na wybrzeże Morza Czarnego. Nie dotarł tam jednak, gdyż zmarł w drodze z wycieńczenia. Relikwie św. Jana Chryzostoma zostały później umieszczone w Konstantynopolitańskim kościele Świętych Apostołów. Za życia był nieustraszonym obrońcą moralności, piętnującym nadużycia wiernych, nawet cesarzy - to właśnie ściągnęło na niego prześladowania.

Jan Chryzostom nie tylko nauczał, mówił piękne i budujące słowa, ale „żył Ewangelią na co dzień”. Można powiedzieć, że był świadkiem tego, co głosił. Dlatego okazywał przebaczenie w praktyce. „Jan nigdy nie potępia ludzi, nawet swych nieprzyjaciół. W ciężkich doświadczeniach życiowych, jakimi były kolejne wygnania, serce jego jest otwarte dla wszystkich dawnych znajomych, a także dla władcy Armenii Sopatera"6.

\section{Jan Chryzostom - pedagog i teolog}

Jan Chryzostom uważany jest za jednego z najwybitniejszych przedstawicieli nurtu określanego mianem pedagogii Ojców. Franciszek Drączkowski pod pojęciem ,pedagogia Ojców i pisarzy Kościoła” rozumie naukę pisarzy wczesnochrześcijańskich o wychowaniu i kształceniu. Uważa, że termin „pedagogia” odnosi się do rzeczywistości złożonej i traktuje o wychowan-

${ }^{4}$ Hans von Campenhausen, Ojcowie Kościoła (Warszawa: PAX, 1967), 144.

5 Tamże, 149.

6 Anna Słomczyńska, „Pisma o charakterze wychowawczym”, w: Jan Chryzostom, Wybór pism, thum. Henryk Paprocki, Wojciech Kania (Warszawa: ATK, 1974), 155-156. 
kach, wychowawcach, procesie prowadzenia (kierowania), to jest metodzie oraz programie formacji intelektualnej oraz moralnej?

Jan Chryzostom był nie tylko wielkim mówcą chrześcijańskiego Wschodu, ale także pedagogiem. Najwięcej rad dla wychowawców zawierają jego homilie. Poglądy pedagogiczne zawarł głównie w dwóch pismach: Jak rodzice winni wychowywać swoje dzieci i O próżnej chwale i wychowaniu dzieci. Celem wychowania, według Jana Chryzostoma, powinno być doprowadzenie dziecka do Boga przez udoskonalenie natury i zbawienie duszy. Osiagnięcie tego celu zależy przede wszystkim od sztuki życia wychowawcy. Pierwszymi wychowawcami są rodzice. Tylko na gruncie dobrze zorganizowanej i zharmonizowanej rodziny udaje się wychowanie ${ }^{8}$.

Jan Chryzostom w rozprawie $O$ wychowaniu dzieci kreśli program ich wychowania, dając priorytet formacji religijno-duchowej ${ }^{9}$. Jego celem jest wychowanie bojowników Bożych, żołnierzy dla Chrystusa. „Wtedy będziemy podobać się Bogu, gdy wychowamy bojowników Bożych. W ten sposób będziemy mogli z dziećmi dojść do dóbr, jakie Bóg obiecał tym, którzy go kochają"10. Z całą pewnością tym obiecanym dobrem jest życie wieczne. Wychowanie ma prowadzić ostatecznie do zbawienia. Ono właśnie, w koncepcji Złotoustego, stanowi cel główny. Ma on charakter religijny, co więcej, pokrywa się i utożsamia z zasadniczym celem chrześcijańskiego życia. Można powiedzieć, że wiara jest punktem odniesienia i inspiracją wszelkich pedagogicznych poczynań. Wyznaczony w ten sposób cel główny determinuje charakter oraz kolejność celów pośrednich.

Złotousty uważa, że dziecko powinno kształcić język, słuch, powonienie, oczy, dotyk. W procesie formacji integralnej „Bożego atlety” przyjmuje zasadę złotego środka, zwracając uwagę na kształtowanie cnót męstwa, odwagi, opanowania, trzeźwości, czujności i hartu ducha i ciała oraz łagodności, uprzejmości, cierpliwości i skromności. Należy wypowiedzieć walkę ta-

7 Franciszek Drączkowski, „Pedagogia Ojców i Pisarzy Kościoła”, w: Encyklopedia pedagogiczna XXI wieku, t. 4, red. Tadeusz Pilch (Warszawa: Wydawnictwo Akademickie „Żak”, 2005), 88.

${ }^{8}$ Stefan Możdżeń, „Ojcowie i pisarze Kościoła - poglądy pedagogiczne”, w: Encyklopedia Pedagogiczna XXI wieku, t. IV, red. Tadeusz Pilch (Warszawa: Wydawnictwo Akademickie „Żak”, 2005), 93.

9 Por. Wojciech Kania, „Pierwsza rodzinna katecheza domowa w ujęciu św. Jana Chryzostoma”, Vox Patrum 5 (1985): 215-222; Henryk Wójtowicz, „Zadania rodziny chrześcijańskiej w nauczaniu św. Jana Chryzostoma”, Vox Patrum 5 (1985): 201-214.

10 Jan Chryzostom, „O wychowaniu dzieci”, w: Jan Chryzostom, Wybór pism, tłum. Henryk Paprocki, Wojciech Kania (Warszawa: ATK, 1974), 168. 
kim wadom jak: gniew, nieopanowanie, pijaństwo i zbytek. Jan Chryzostom wiele uwagi poświęca kształtowaniu wstrzemięźliwości seksualnej. Ukoronowaniem całej formacji jest mądrość, która jest przede wszystkim wiedzą o Bogu, o dobrach, które są po tamtej stronie, o piekle, o królestwie niebieskim. Chociaż dzieci trzeba przygotować do udziału w życiu publicznym, to jednak należy to łączyć z dystansem wobec dóbr tego świata ${ }^{11}$.

Papież Benedykt XVI przypominał sylwetkę św. Jana Chryzostoma podczas audiencji generalnych 19 i 26 września 2007 roku$^{12}$. Benedykt stwierdził, że Chryzostom, mówiąc o ośmiu dziełach dokonanych przez Boga w ciagu kolejnych sześciu dni, pragnie poprowadzić wiernych od stworzenia do Stwórcy. Ukazuje piękno stworzenia oraz Boga przejawiającego się w Jego stworzeniu, które przez to staje się jak gdyby „schodami” prowadzącymi do Boga, do Jego poznania. Do tego pierwszego obrazu dochodzi drugi: ten Bóg Stwórca jest również Bogiem zniżającym się ku człowiekowi (synkatabasis). My jesteśmy słabi we „wznoszeniu się”, nasze oczy są słabe. Dlatego Bóg staje się łaskawy, posyła upadłemu i wyobcowanemu człowiekowi list, Pismo Święte, tak że stworzenie i Pismo Święte uzupełniają się. W świetle Pisma Świętego, listu przekazanego nam przez Boga, możemy odczytać stworzenie. Bóg nazwany jest „czułym ojcem” (philostorgios), lekarzem dusz, matką i serdecznym przyjacielem. A do tego drugiego obrazu - najpierw stworzenie jako ,schody” prowadzące ku Bogu, a potem zniżenie się Boga przez przekazany nam list, Pismo Święte - dochodzi trzeci. Bóg nie tylko przekazuje nam list - ostatecznie On sam zstępuje, wciela się, staje się „Bogiem z nami”. Do tych trzech obrazów - Bóg jest widzialny w stworzeniu, przekazuje nam swój list, zstępuje i staje się jednym z nas - dochodzi na koniec czwarty. W życiu i działaniu chrześcijanina zasadą witalną i dynamiczną jest Duch Święty (Pneuma), przemieniający rzeczywistość świata. Bóg wkracza w nasze życie przez Ducha Świętego i przemienia nas, poczynając od naszego serca.

Według Benedykta Jan Chryzostom przez swoje pisma stara się wspomagać integralny rozwój osoby — w wymiarze fizycznym, intelektualnym i religijnym. Poszczególne fazy wzrostu porównywane są do różnych mórz olbrzymiego oceanu. Pierwszym z tych mórz jest dzieciństwo (Homilia 81, 5

${ }_{11}$ Drączkowski, „Pedagogia, 91-92.

${ }_{12}$ Por. Benedykt XVI, „Św. Jan Złotousty - wielki teolog i kaznodzieja”, Audiencja generalna, 19 września 2007, L'Osservatore Romano 12 (2007): 30-31; Benedykt XVI, „Św. Jan Chryzostom jednym z ojców społecznej nauki Kościoła”, Audiencja generalna, 26 września 2007, L'Osservatore Romano 12 (2007): 31-32. 
z Wykładu Ewangelii św. Mateusza) - wówczas ujawniają się skłonności do błędu i do cnoty. Dlatego też prawo Boże powinno zostać od samego początku wyryte w duszy jak na woskowej tabliczce (Homilia 3, 1 do Ewangelii św. Jana). Zasadniczą kwestią jest to, by rzeczywiście człowiek w tej pierwszej fazie życia otrzymał główne wskazania, które nadadzą mu właściwą perspektywę. Dlatego Chryzostom zaleca: „Już od najwcześniejszych lat wyposażcie dzieci w duchowy oręż i nauczcie je czynić ręką na czole znak krzyża" (Homilia 12, 7 na Pierwszy List do Koryntian). Później przychodzi wiek dojrzewania i młodości ,kiedy to wieją gwałtowne wichry, (...) ponieważ rośnie w nas (...) pożądanie" (Homilia 81, 5 z Wykładu Ewangelii św. Mateusza). Kolejnym etapem jest narzeczeństwo i małżeństwo: „Po wieku młodzieńczym nastaje wiek dojrzały, w którym dochodzą obowiązki rodzinne; jest to czas szukania żony" (Homilia 81, 5 z Wyktadu Ewangelii św. Mateusza). Złotousty uwypukla cele małżeństwa i wzbogaca je o sieć międzyosobowych relacji. I tak, dobrze przygotowanym małżonkom nie zagraża rozwód: wszystko odbywa się w radości, i można dzieci wychowywać do cnoty. Kiedy zaś rodzi się pierwsze dziecko, staje się ono ,jakby pomostem; trójka staje się jednym ciałem, ponieważ dziecko łączy obie strony" (Homilia 12, 5 na List do Kolosan), a troje stanowi „rodzinę, mały Kościół” (Homilia 20, 6 na List do Efezjan).

Jan Chryzostom łączy w sobie rolę teologa i pedagoga. Źródłem inspiracji wychowawczych jest dla niego zawsze Słowo Boże i prawda o Bogu, który ukochał człowieka i nie pozostawia go samego w jego upadku. Dlatego zachęca ludzi do naśladowania Boga przez przyjęte i ofiarowane przebaczenie.

\section{Czlowiek potrzebujący przebaczenia}

Żeby zrozumieć naukę Jana Chryzostoma o przebaczeniu, należy poznać jego myśli dotyczące pochodzenia i natury człowieka. Jak zauważa Sylwia Kaczmarek, Jan Chryzostom w homiliach na Księgę Rodzaju kładzie nacisk na problemy antropologiczne, związane z zaistnieniem człowieka, $\mathrm{z}$ jego miejscem we wszechświecie, $\mathrm{z}$ jego relacjami z innymi, z napotykanymi trudnościami, doświadczanymi przez niego zależnościami, a w końcu z sensem życia, śmierci i z perspektywą wieczności ${ }^{13}$.

13 Jan Chryzostom, Homilie na Księgę Rodzaju (seria pierwsza Rdz 1-3) (Kraków: WAM, 2008), 36-37. 
Antropologia Jana Chryzostoma opiera się na biblijnym opisie stworzenia człowieka na „obraz i podobieństwo” Boga. Osią homilii II na Księgę Rodzaju jest analiza słów: „uczyńmy i na obraz” (Rdz 1,26). W słowie „uczyńmy” Złotousty odczytuje informację o porozumiewaniu się Boga z kimś równym $\mathrm{Mu}$ godnością. Chryzostom godność człowieka dokumentuje wolą zbawczą Boga, który nie zawahał się ofiarować swego Syna. Argumentem za królewską godnością człowieka jest fakt, że został stworzony na końcu, gdy wszystko było dla niego przygotowane. Stwierdza: „Kimże jest ten, kto ma być stworzony, że tak wielkiej czci doznaje? To jest człowiek: wielka i godna podziwu istota, cenniejsza dla Boga niż cała reszta stworzenia, ze względu na którą istnieje niebo i ziemia, i morze, i każdy element stworzenia; człowiek, którego zbawienia Bóg tak pragnął, że dla niego nie oszczędził nawet Jednorodzonego" (II, 1). Antiocheńczyk podważa sensowność dopatrywania się podobieństwa pomiędzy Bogiem i człowiekiem w aspekcie istoty - twierdzi, że Bóg nie mówił o obrazie istoty, lecz o obrazie władzy (II, 2).

W homilii III na Księgę Rodzaju Jan Chryzostom dopełnia interpretacji wersetu Rdz 1, 26 poprzez wyjaśnienie sformułowania „podobieństwo”. Według niego wyrażenie z Rdz 1, 26 „na obraz” nie stwierdza braku różnicy pod względem istoty, ale podobieństwo odnośnie do władzy.

Usłyszeliśmy, że Bóg uczynił człowieka na obraz. Powiedzieliśmy też, co to znaczy: „na obraz” oraz co to znaczy: „na podobieństwo”. Pierwsze sformułowanie nie stwierdza braku różnicy pod względem istoty, ale podobieństwo odnośnie do władzy. „Na podobieństwo” dotyczy natomiast bycia uległym i cichym oraz naśladowania w miarę możności Boga w dziedzinie cnoty, jak rzecze Chrystus: „Stawajcie się podobni do Ojca mojego w niebiosach” (III, 1).

„Na podobieństwo" dotyczy zatem, według Chryzostoma, bycia uległym i cichym oraz naśladowania $\mathrm{w}$ miarę możności Boga $\mathrm{w}$ dziedzinie cnoty. Definiuje on podobieństwo człowieka do Boga jako uległość i cichość, związane z naśladowaniem Boga w cnocie. Według Złotoustego, człowiek może dojść do osiagnięcia tego podobieństwa, jeśli chce: „Jeśli zechcesz, możesz być uległy i cichy" (III, 1).

Winę człowieka Antiocheńczyk wiąże z nieposłuszeństwem Bogu. W homilii IV na Księgę Rodzaju Złotousty rozpatruje konsekwencje grzechu, to znaczy utratę panowania oraz popadnięcie w niewolę. Władza powierzona człowiekowi przez Boga nie była wynikiem jego zasług czy odpłatą Boga, lecz aktem Bożej miłości. Człowiek zaś przez nieposłuszeństwo 
i gnuśność pozbawił się swej królewskiej godności i przez grzech skrępował swą naturę więzami. Jan Chryzostom stwierdza: „Z Bogiem jest jednak inaczej: doprowadził człowieka do wielkiej godności zaraz po stworzeniu, ukazując przez to, że nie jest to zapłata za dobre czyny, lecz łaska Boża; nie jest to też powinność. Uzyskanie przez człowieka władzy dokonało się jedynie za sprawą Bożego miłosierdzia; natomiast utrata władzy była efektem jego własnej gnuśności” (IV, 1) czy w innym miejscu: „Nie myśl, że to Bóg z konieczności ją zaprowadził, lecz że to grzech utworzył samą naturę niewoli” (IV, 2). W homilii V na Księgę Rodzaju Chryzostom podkreśla, że wieloraka niewola człowieka nie wywodzi się z natury, lecz z grzechu: „ci, którzy byli na początku, zgrzeszyli i przez swe nieposłuszeństwo wprowadzili niewolę; natomiast ci, którzy żyli później, potwierdzili wprowadzoną niewolę swoimi grzechami” (V, 1); ,Jak bowiem nie wszystkie nieuleczalne choroby są tej samej natury, a mimo to wszystkie prowadzą do śmierci, tak nie wszystkie grzechy są tej samej natury, a mimo to wszystkie powodują niewolę" $(\mathrm{V}, 1)$.

Jednak przez wiarę niewolnik może stać się wyzwoleńcem w Chrystusie, a poprzez cnotę rządzony może stać się bardziej królewski od rządzącego. Możliwe jest zatem dojście człowieka do stanu „rajskiego”: „Chrystus przyszedł nam z pomocą i obiecał nam teraz dobra większe od tamtych, z których pierwsi ludzie wyzuli nas przez grzech" (V, 2). Potwierdza to Złotousty także w innych słowach:

Jakże więc łotr mógł otrzymać dobra? Przecież Bóg nie do raju obiecuje nas wprowadzić, ale do nieba; i nie królestwo rajskie, a królestwo niebieskie ogłosił. (...) Utraciłeś zatem raj, ale Bóg dał ci niebo, aby okazać własne miłosierdzie, i podrażnić diabła. (...) Utraciłeś wprawdzie raj, ale Bóg otwarł ci niebo. Zostałeś skazany na tymczasowy trud, a uczczony zostałeś życiem wiecznym (VI, 5).

Bóg ulepił człowieka z ziemi i wody i umieścił go w raju. Ulepiony człowiek nie okazał się przydatny, lecz uległ deformacji. Następnie już nie z ziemi i z wody na nowo go kształtuje, ale z wody i Ducha; i już nie raj mu obiecuje, ale królestwo niebieskie (VI, 5).

Bóg jest tym, który administruje karami i ze zła stara się wyprowadzić dobro. „Jak czuły ojciec wzbudzającym strach pedagogom i nauczycielom powierza dzieci, które o niego nie dbają i lekceważą go z powodu jego ojcowskiej czułej miłości, podobnie czyni Bóg: Niczym nauczycielom i peda- 
gogom powierzył On naszą naturę, lekceważącą Go z powodu Jego dobroci, sprawującym władzę, żeby ich odwiedli od gnuśności” (IV, 2).

Odebranie godności i pojawienie się lęku są wyrazem pedagogicznej troski Boga o człowieka. Wartość kary polega na tym, że motywuje człowieka do nawrócenia. Wyrok zdobywania pożywienia w pocie czoła Chryzostom zestawia z postawą pana, który karze sługę, pielęgnując zarazem jego rany. Znakiem troski o to, by kara nie była nie do zniesienia, jest pozostawienie człowiekowi pomocy w postaci przydatniejszych dla niego zwierząt. „Jak miłosierny i troskliwy pan, który chłoszcze swego sługę, ale stosuje też pewną kurację wobec zadanych batami ran, tak i Bóg nakłada karę, ale na wszelki sposób chce uczynić tę karę lżejszą. Dlatego zasądziwszy nas na pot i nieustanny trud, dostarczył nam liczne gatunki nierozumnych istot, aby miały udział w naszym trudzie” (III, 2). „Popatrz teraz na Jego niewypowiedziane miłosierdzie. Adam odrzucił całe polecenie i przekroczył prawo, Bóg natomiast nie unieważnił całej jego godności, ani nie pozbawił go wszelkiego panowania" (III, 2).

Myśli dotyczące wychowania człowieka po grzechu zawiera pismo Do Teodora po jego upadku ${ }^{14}$. Anticheńczyk przedstawia Boga jako lekarza, który działa nie po to, aby się pomścić za nasze niewłaściwe czyny, lecz po to, aby nas uleczyć.

Nie dla siebie karze Bóg tych, co przeciw Niemu zgrzeszyli (w Jego naturę nie zdoła się wcisnąc żadna obraza), lecz ma na względzie dobro i chce, abyśmy się nie stali gorsi, mniemając, że nie zwraca On na nic uwagi. Jak ten, kto usuwa się od światła, nie światłu czyni szkodę, lecz sobie, schodząc w ciemność, tak i ten, kto gardzi wszechpotężną mocą, nie jej, lecz sobie gotuje wielką zgubę. Dlatego grozi nam Bóg karą i często ją zsyła nie dla zemsty, lecz po to, by nas do siebie pociaggnąć. Nie czuje się jak obrażony lekarz, gdy go znieważają ci, co postradali zmysły, i nie bacząc na to czyni wszystko, aby ich od złego powstrzymać, mając na uwadze nie własną korzyść, lecz ich dobro, i kiedy chorzy okażą choć trochę zdrowego rozsądku, raduje się i cieszy, i z nowym zapałem stosuje lekarstwo, by im przywrócić jeszcze więcej dobra, a nawet całkowite zdrowie; podobnie czyni Bóg w naszej głupocie, nie żeby się pomścić za nasze czyny, lecz by nas uwolnić od choroby (I, 4).

14 Jan Chryzostom, „Do Teodora po jego upadku”, w: Jan Chryzostom, Wybór pism, thum. Henryk Paprocki, Wojciech Kania (Warszawa: ATK, 1974), 192-238. 
Złotousty daje konkretne przykłady osób, które okazały skruchę i doświadczyły przebaczenia ze strony miłosiernego Boga. Dotyczy to króla Dawida:

Natura ludzka, narażona na niebezpieczeństwa, łatwo daje się uwieść, choć też łatwo się uwalnia z oszustwa - $\mathrm{i}$ jak prędko upada, tak jeszcze prędzej powstaje. Toteż i ów święty mąż Dawid, wybrany na króla i proroka, choć wiele dobrego uczynił, okazał się jeszcze człowiekiem i uległ miłości cudzej kobiety i nie poprzestał na tym, lecz wskutek pożądliwości popełnił cudzołóstwo, a po cudzołóstwie zabójstwo. Gdy jednak otrzymał dwie tak wielkie rany, nie dodał jeszcze trzeciej, lecz natychmiast pobiegł do lekarza i zastosował lekarstwa - post, żal, liczne modlitwy, częste wyznanie grzechów, przepraszając w ten sposób Boga. Toteż wrócił do pierwszej godności i mimo cudzołóstwa i zabójstwa pamięć ojca zdołała przykryć bałwochwalstwo syna Salomona, który w tę samą, co ojciec sieć złapany, od ojcowskiego Boga odszedłszy, uległ kobietom (II, 2).

Innym „przypadkiem” jest król Nabuchodonozor:

Któż - powiedz - był bardziej bezbożny niż król babiloński Nabuchodonozor? Doświadczył on tak wielkiej Bożej mocy, że padł na twarz przed prorokiem i kazał złożyć mu ofiarę i miłe wonie, lecz znów potem popadł w dawną pychę i tych, którzy go nie czcili więcej niż Boga, wrzucił związanych do rozpalonego pieca. A jednak tego okrutnego bezbożnika, którego należało nazwać raczej zwierzęciem niż człowiekiem, wezwał Bóg jeszcze do pokuty i dał mu sposobność do zmiany życia - najpierw cud w piecu ognistym, a potem widzenie, które wyjaśnił Daniel, zdolne ugiąć nawet zakamieniałą duszę. Wreszcie po tym upomnieniu przez rzeczy dał mu prorok radę, mówiąc: Dlatego, królu, przyjmij moją radę i okup swe grzechy uczynkami sprawiedliwymi, a swe nieprawości miłosierdziem wobec ubogich; wtedy może będzie miłosierdzie dla twych grzechów. Co mówisz, błogosławiony mędrcu? Czy możliwa jest jeszcze poprawa po takim upadku i zdrowie po takiej chorobie? I po takim szaleństwie nadzieja zdrowego rozumu? (I, 5).

Jan Chryzostom przypomina, że Bóg zawsze jest gotowy okazać przebaczenie człowiekowi, który wykazuje chociażby najmniejszą chęć podjęcia pokuty i przyjęcia przebaczenia:

Jak wielka jest miłość Boga względem ludzi! Nigdy się nie odwraca od szczerej pokuty, lecz choćby kto doszedł do szczytu nieprawości i stąd chciał wrócić na 
drogę cnoty, przyjmuje go łaskawie i czyni wszystko, by go przyprowadzić do pierwotnego stanu. Owszem, jeszcze dalej sięga Jego miłosierdzie. Choćby kto nie okazywał całkowicie dostatecznej pokuty, ale nie wzbraniał się przynajmniej przed pokutą krótką i małą, i tak mu nie omówi wielkiej nagrody $(\mathrm{I}, 6)$.

\section{Czlowiek przebaczający}

Święty Jan Chryzostom reprezentuje nurt tradycyjnej nauki Ojców Kościoła na temat natury ludzkiej. Nauka ta przetrwała do naszych czasów w Kościele rzymskokatolickim. Natura czysta (status naturae purae) istnieje tylko hipotetycznie, już bowiem od momentu stworzenia zostaje wyniesiona przez Boga do porządku nad-natury (status naturae integrae). W takim stanie - natury zintegrowanej, zespolenia łaski z natura - człowiek przebywał do czasu grzechu pierworodnego. Przez grzech pierworodny człowiek znalazł się w stanie natury upadłej (status naturae lapsae). Ale decyzją wolnej woli dzięki łasce Bożej może przejść do stanu natury odkupionej (status naturae reparatae). W takim stanie człowiek nie tylko może przyjmować Boże przebaczenie, ale może przebaczać innym, upodabniając się do Boga.

Człowiek, który przez grzech popadł w różnoraką niewolę, potrzebuje zmiany w życiu - przebaczenia. W duszy człowieka łatwo może zajść każda zmiana, ponieważ to, co duchowe, zależy od wolnej woli i intencji, a nie przynależy do natury. Jan Chryzostom wyjaśnia to zagadnienie w Katechezach chrzcielnych ${ }^{15} \mathrm{w}$ następujący sposób:

Widzisz kochany, iż jest tu mowa o duszy. Naturalna brzydota ciała nigdy nie zmieni się w piękność, gdyż Pan uczynił naturę niezmienną. Jeśli zaś chodzi o duszę, jest to proste, a nawet bardzo łatwe. Dlaczego i w jaki sposób? To wszystko zależy od wolnej woli, a nie od natury. Nawet bezkształtna i bardzo brzydka dusza, jeśli tylko zechce, może się przemienić, dojść do wielkiej piękności i stać się promienną. I przeciwnie: gdy się zaniedba, popadnie w wielką szpetotę $(I, 10)$.

Złotousty uważa, że człowiek, który poprzez swoją wolność i wolne decyzje sprzeciwił się Bogu, może w sposób wolny przyjąć Boże przebaczenie i co więcej, może okazywać innym przebaczenie. To „okazywanie przeba-

15 Jan Chryzostom, Katechezy chrzcielne (homilie katechetyczne do tych, którzy maja być oświeceni oraz do neofitów), U źródet katechumenatu 1 (Lublin: Kerygma, 1993). 
czenia” staje się „lekarstwem na nasze rany”, a także sprawia, że stajemy się podobni do przebaczającego Boga.

W modlitwie Ojcze nasz jest fraza, która zawiera wezwanie do przebaczenia: „przebacz nam nasze winy, jak i my przebaczamy tym, którzy przeciw nam zawinili" (Mt 6, 12). Przebaczenie winowajcom jest ściśle powiązane $\mathrm{z}$ otrzymaniem przebaczenia od Boga. Biblia Tysiąclecia jest w tym przekładzie konsekwentna i nie pozostawia żadnej wątpliwości: ,jeśli bowiem przebaczycie ludziom ich przewinienia, i wam przebaczy Ojciec wasz niebieski. Lecz jeśli nie przebaczycie ludziom, i Ojciec wasz nie przebaczy wam waszych przewinień" (Mt 6, 14-15). Znany polski biblista, Waldemar Chrostowski, komentując ten fragment Modlitwy Pańskiej zauważa, że istotnym sposobem wyrażania miłosierdzia jest przebaczenie i dawanie. Skoro doznajemy miłosierdzia od Boga, który niestrudzenie nam przebacza, powinniśmy wejść na drogę przebaczania innym ${ }^{16}$.

W Homiliach na Ewangelię według św. Mateusza Jan Chryzostom zaznacza, że „nic nie czyni nas tak podobnymi do Boga jak przebaczenie” $(19,7)$. W komentarzu do piątej prośby Modlitwy Pańskiej Antiocheńczyk podkreśla, że odpuszczenie (przebaczenie) zależy w pierwszym rzędzie od nas, i w naszej władzy pozostaje wyrok, który na nas zostanie wydany. W homilii XVI stwierdza: „Ciebie, któryś sam jesteś winien, Zbawiciel czyni sędzią nad tobą samym i jakby mówi: jaki wyrok wydasz sam na siebie, taki wyrok i Ja wydam na ciebie, wybaczysz swojemu bratu, to i ode Mnie otrzymasz takie same dobrodziejstwo" $(61,5)$. Dla Złotoustego modlitwa o ukaranie wrogów jest nierozumna. Jest ciężką obrazą Boga. „Zwracasz się - pisze z prośbą do Boga i (...) zapominając o modlitwie, zaczynasz złorzeczyć na swojego wroga i bezcześcisz przykazania Boże, wzywając Boga, który nakazał odrzucić wszelki gniew przeciwko tym, którzy cię obrazili i prosząc Go o to, co sprzeciwia się Jego własnym przykazaniom” $(61,5)$. „Są ludzie pisze dalej św. Jan - którzy doszli do takiego szaleństwa, że nie tylko modlą się, nienawidząc wrogów, lecz nawet przeklinają ich dzieci” $(61,5)$. Po bardzo ostrym potępieniu tak postępujących ludzi św. Jan pisze: „przestańmy chorować na takie szaleństwo: okażmy życzliwość tym, którzy nas obrazili, tak jak nakazał to Pan (...) stańmy się podobnymi do naszego Ojca w niebiosach”. Jan Chryzostom mówi: „Lecz ty doznałeś krzywdy, choć wyświadczyłeś dobrodziejstwa? Dlatego właśnie smuć się i ubolewaj nad tym, który to uczynił, a nad sobą samym się raduj, że stałeś się podobny Bogu" $(61,5)$.

16 Waldemar Chrostowski, Uczynki miłosierdzia względem ciała i ducha w świetle Biblii (Kraków: Wydawnictwo Biały Kruk, 2016), 13. 
Dzięki przebaczeniu człowiek leczy swoje rany. Będąc miłosiernymi, odrzucając gniew wobec tych, którzy nas rozgniewali, stajemy się podobnymi do przebaczającego Boga. Wyraźnie potwierdza to Jan Chryzostom w komentarzu do listu św. Pawła do Galatów ${ }^{17}$. Komentując rozdział VI tegoż listu, Złotousty nakazuje łagodne traktowanie grzeszących:

Bracia, gdyby człowiek został przyłapany na grzechu. Nie powiedział ,jeśli popełnił", lecz: Gdyby został przyłapany, wówczas Wy jako uduchowieni, poprawcie go. Nie polecił: „Ukarzcie”, ani: „Potępcie”, lecz: Poprawcie. Nie poprzestaje na tym. Dąży do pouczenia, iż powinni być bardziej łagodni wobec tych, którzy potknęli się. Dorzuca więc: W duchu łagodności. Nie: „W łagodności", ale: $\mathrm{W}$ duchu łagodności, chcąc w ten sposób dowieść, że jest to miłe Duchowi, gdyż jest łaską Ducha łagodne traktowanie grzeszących ${ }^{18}$.

Antiocheńczyk przestrzega przed postawą pychy, wywyższania się. Zaleca, aby nie skupiać swojej uwagi na grzechach, lecz wypełniać prawo Boże, przebaczając sobie wzajemnie.

Następnie, aby ten, kto pomaga drugiemu naprawić błędy, nie stał się zarozumiały, ostrzega: bacząc na siebie samego, abyś i ty nie uległ pokusie (...). Jeden drugiego brzemiona noście. Wobec tego, że człowiek nie może być wolnym od niedoskonałości, nalega, aby ponad miarę nie zajmować się grzechami innych. Powinniśmy okazywać zrozumienie dla wad bliźnich, jeżeli chcemy, aby i nam inni wybaczyli (...). I tak wypełnicie prawo Chrystusa. Nie powiedział: „Spełnicie”, lecz: wypełnicie, to znaczy, że tolerując jedni drugich, wszyscy razem spełnicie [prawo Chrystusa - S. Ch.]. Przykładowo, jeśli jeden z was jest porywczy, a drugi ospały, to w takim przypadku znoś jego wybuchy, aby on ścierpiał twoją gnuśność. W konsekwencji, ani on nie zgrzeszy, jeśli napotka zrozumienie z twojej strony, ani ty nie zgrzeszysz, gdyż twój brat ścierpiał nieznośne dla niego twoje poczynania. Tym sposobem, podając sobie rękę w chwili grożącej upadkiem, wspólnie wypełnicie prawo. Niech z cierpliwością spotka się każdy błąd bliźniego. Postępując inaczej, to znaczy, roztrząsając wady bliźniego, nie osiagniecie zamierzonego celu ${ }^{19}$.

\footnotetext{
17 Jan Chryzostom, Komentarz do listu św. Pawła do Galatów (Kraków: WAM, 2008).

18 Tamże, 126.

19 Tamże, 127.
} 


\section{Podsumowanie}

Pedagogia Jana Chryzostoma, tak jak cała pedagogia Ojców Kościoła, zakorzeniona jest w Biblii. Tylko perspektywa Słowa Bożego i życia wiecznego nadaje ostateczny sens wszelkim procesom wychowawczym. Pedagogiczne nauczanie Złotoustego na temat przebaczenia jest ściśle powiązane z teologiczną wizją człowieka i jego natury, jaką odnajdujemy w Biblii.

W biblijnym rozumieniu człowiek popełniający grzech zaciaga dług, staje się dłużnikiem Boga, który może ten dług darować. Darowanie jest pojmowane niemal tak jak darowanie materialnego długu. Bóg nie dostrzega już darowanego grzechu; jest on rzucony poza Niego, zostaje zgładzony, odpokutowany, zniszczony ${ }^{20}$.

Z ludzkiego punktu widzenia taka postawa Boga, który przebacza, często jest niezrozumiała. Ale człowiek potrzebuje przebaczenia, aby zostać uwolnionym z różnorakiej niewoli, w którą popada poprzez grzech. Przyjęcie w sposób wolny przebaczenia od Boga przywraca człowiekowi utracony „stan rajski”. Równocześnie, jak przypomina Złotousty, człowiek może stać się podobnym do Boga poprzez przebaczenie ofiarowane innym nawet wówczas, kiedy są naszymi dłużnikami.

\section{A Man Suchlike God through Forgiveness in the Teaching of St. John Chrysostom (Summary)}

In the realities of today's world, the education of the Church Fathers regarding forgiveness among others, it is worth reminding. The aim of the hereby text is to reflect on the phenomenon of forgiveness in the teachings of one of the first teachers of Christianity - St. John Chrysostom. His teachings are included mainly in comments to the Bible. Chrysostom explains what forgiveness truly means by commenting on the Gospel by St. Mathew (chapter VI) and the Letter of St. Paul to the Galatians (chapter VI). To understand the essence of forgiveness, one must first embrace the anthropological thought of the Antiocheńczyk reaching to His homily on the Book of Genesis and scripture To Theodore after his fall. This article recalls the most important facts of John Chrysostom's life, shows him as a teacher to further bring

${ }^{20}$ Por. Jean Giblet, Marc-Francois Lacan, „Przebaczenie”, w: Słownik teologii biblij$n e j$, red. Xavier Leon-Dufour; thum. Kazimierz Romaniuk (Poznań-Warszawa: Pallottinum, 1973), 799-800. 
closer the teachings of the human being who needs forgiveness and also forgives, as „nothing makes us so like God, as being ready to forgive the wicked and wrong-doers".

Key words: teaching of the Fathers; a man needing forgiveness; a man forgiving.

\section{Człowiek podobny do Boga przez przebaczenie w nauczaniu Świętego Jana Chryzostoma \\ (Streszczenie)}

W realiach dzisiejszego świata warto przypominać pedagogię Ojców Kościoła dotyczącą między innymi przebaczenia. Celem niniejszego tekstu jest refleksja nad fenomenem przebaczenia w nauczaniu jednego z pierwszych pedagogów chrześcijańskich, jakim był św. Jan Chryzostom. Jego nauczanie zawarte jest głównie w komentarzach do Pisma Świętego. Złotousty wyjaśnia, czym jest przebaczenie, komentując przede wszystkim teksty Ewangelii według św. Mateusza (rozdział VI) oraz List św. Pawła do Galatów (rozdział VI). Aby zrozumieć istotę przebaczenia, należy jednak najpierw ukazać myśl antropologiczną Anticheńczyka, sięgając do jego homilii na Księgę Rodzaju oraz pisma Do Teodora po jego upadku. Artykuł przypomina najważniejsze fakty z życia Jana Chryzostoma, ukazuje go jako pedagoga, aby następnie przybliżyć naukę o człowieku potrzebującym przebaczenia i przebaczającym, bowiem „nic nas tak Bogu podobnymi nie czyni, jak gdy złym i takim, którzy nam krzywdę czynią, przebaczamy".

Słowa klucze: pedagogia Ojców; człowiek potrzebujący przebaczenia; człowiek przebaczający.

\section{Bibliografia}

Benedykt XVI. „Św. Jan Chryzostom jednym z ojców społecznej nauki Kościoła”. Audiencja generalna, 26 września 2007. L'Osservatore Romano 12 (2007): 31-32.

Benedykt XVI. „Św. Jan Złotousty - wielki teolog i kaznodzieja”. Audiencja generalna, 19 września 2007. L'Osservatore Romano 12 (2007): 30-31.

Campenhausen, Hans von. Ojcowie Kościoła. Warszawa: PAX, 1967.

Chrostowski, Waldemar. Uczynki miłosierdzia względem ciała i ducha w świetle Biblii. Kraków: Wydawnictwo Biały Kruk, 2016. 
Chryzostom, Jan. „Do Teodora po jego upadku”. W: Jan Chryzostom, Wybór pism, thum. Henryk Paprocki, Wojciech Kania, 192-238. Warszawa: ATK, 1974.

Chryzostom, Jan. „O wychowaniu dzieci”. W: Jan Chryzostom, Wybór Pism, tłum. Henryk Paprocki, Wojciech Kania, 157-185. Warszawa: ATK 1974.

Chryzostom, Jan. Homilie na Ewangelię wedtug św. Mateusza. Kraków: WAM, 2003.

Chryzostom, Jan. Homilie na Księgę Rodzaju (seria pierwsza Rdz 1-3). Kraków WAM: 2008.

Chryzostom, Jan. Katechezy chrzcielne (homilie katechetyczne do tych, którzy maja być oświeceni oraz do neofitów). U źródeł katechumenatu 1. Lublin: Kerygma 1993.

Chryzostom, Jan. Komentarz do listu św. Pawła do Galatów. Kraków: WAM, 2008. Chryzostom, Jan. Wybór pism, tłum. Henryk Paprocki, Wojciech Kania. Warszawa: ATK, 1974.

Drączkowski, Franciszek. „Pedagogia Ojców i Pisarzy Kościoła”. W: Encyklopedia pedagogiczna XXI wieku, t. 4, red. Tadeusz Pilch, 88-92. Warszawa: Wydawnictwo Akademickie „Żak”, 2005.

Franciszek. Bulla MisericordiaeVultus. Poznań: Pallotinum, 2015.

Giblet, Jean, Marc-Francois Lacan. „Przebaczenie”. W: Stownik teologii biblijnej, red. Xavier Leon-Dufour, tłum. Kazimierz Romaniuk, 799-803. Poznań-Warszawa: Pallottinum, 1973.

Kania, Wojciech. „Pierwsza rodzinna katecheza domowa w ujęciu św. Jana Chryzostoma”. Vox Patrum 5 (1985): 215-222.

Kelly, John N. D. Złote Usta. Jan Chryzostom - asceta, kaznodzieja, biskup, thum. Katarzyna Krakowczyk. Bydgoszcz: Homini, 2001.

Możdżeń, Stefan. „Ojcowie i pisarze Kościoła - poglądy pedagogiczne”. W: Encyklopedia pedagogiczna XXI wieku, t. 4, red. Tadeusz Pilch, 92-97. Warszawa: Wydawnictwo Akademickie ,Żak”, 2005.

Słomczyńska, Anna. „Pisma o charakterze wychowawczym”. W: Jan Chryzostom, Wybór pism, tłum. Henryk Paprocki, Wojciech Kania, 153-156. Warszawa: ATK, 1974.

Wójtowicz, Henryk. „Zadania rodziny chrześcijańskiej w nauczaniu św. Jana Chryzostoma”. Vox Patrum 5 (1985): 201-214. 